\title{
ЕЛЕКТРОХІМІЧНІ ЗАКОНОМІРНОСТІ КОРОЗІЙНО-МЕХАНІЧНОГО РУЙНУВАННЯ ТИТАНОВИХ СПЛАВІВ
}

\author{
Олег Калахан, д. т. н. \\ Львівський національний аграрний університет, \\ вул. Володимира Великого, 1, м. Дубляни, Львівський р-н, Львівська обл., Украӥна, \\ e-mail:oleg.kalakhan@gmail.com
}

https://doi.org/10.31734/agroengineering2021.25.113

Калахан О. Електрохімічні закономірності корозійно-механічного руйнування титанових сплавів На підставі кореляційних змін на поверхні й електродного потенціалу ідентифіковано характерні ділянки, які відповідають окремим етапам процесу корозійної багатоциклової втоми титанових сплавів різного структурнофазового стану: руйнування захисних оксидних плівок; пасивація свіжоутворених поверхонь (СУП); утворення мікротріщин та їх розвиток у макротріщину; субкритичний ріст магістральної тріщини та спонтанне руйнування. Утворення захисних оксидних плівок на недеформованих і циклічно деформованих титанових $\alpha$ - i $(\alpha+\beta)$-сплавах констатували, усуваючи з їхної поверхні оксиди і визначаючи зміщення потенціалу та поведінку за зовнішньої поляризації, а також після призупинення оновлення поверхні - за швидкістю зміни електродного потенціалу та струму. 3'ясовано, що потенціал СУП титанових сплавів ( $\tau=5 \mathrm{~ms})$ знешляхетнюється та наближається до величини зворотного потенціалу анодної реакції $\mathrm{Ti}+\mathrm{H}_{2} \mathrm{O}=\mathrm{TiO}+2 \mathrm{H}^{+}+2 \bar{e}\left(\varphi_{a}^{0}=-1,31 \mathrm{~V}\right)$, неоднозначно залежить від концентрації $\mathrm{Cl}^{-}$-іонів у діапазоні $0,1-1,5 \mathrm{~N}$ розчинів $\mathrm{NaCl}$. Регенерація пасивності сплавів у перші секунди відбувається за лінійним законом із подальшим уповільненням і стабілізацією до $1 \mathrm{~h}$. Регенерація пасивності циклічно деформованих сплавів характеризується етапною зміною і потенціалу, і струму. На перших етапах їхній спад описується прямою лінією в координатах напруга (струм) - логарифм часу експозиції за різних кутових коефіцієнтів. На третьому етапі потенціал СУП досягає значення, що дорівнює потенціалу сплаву до оновлення поверхні. Характер зміни $i-t$ кривих без і за наявності деформацій однаковий, але під дією деформації струм знижується швидше і за час експозиції до $10 \mathrm{~s}$ зменшується до стаціонарного значення.

Ключові слова: титанові сплави, корозія, електродний потенціал, поляризація, репасивація, деформація, механізм, електрохімічна кінетика.

\section{Kalakhan O. Electrochemical regularities of the corrosion-mechanical fracture of titanium alloys}

The mechanism and kinetics of corrosion-fatigue fracture of titanium alloys of different phase composition $(\alpha$, pseudo- $\alpha, \alpha+\beta)$ are considered using the electrochemical investigations, namely the change of electrode potential $E$ during specimens deformation (dependences $E-\lg N$ ), external polarization. The electrochemical processes on the fresh surface (FS) for time $\tau=5 \cdot 10^{-3} \mathrm{~s}$ of their interaction with sodium chloride solutions of different concentration $(0.1 ; 0.5 ; 1.0$ and $1.5 \mathrm{~N}$ solution) are studied. The FS potential of titanium alloys for the time of formation $\tau \cong 5 \cdot 10^{-3} \mathrm{~s}$ shifts into cathodic region of values and approaches to the reverse potential of anodic reaction $\mathrm{Ti}+\mathrm{H}_{2} \mathrm{O}=\mathrm{TiO}^{+}+2 \mathrm{H}^{+}+2 \overline{\mathrm{e}}, \varphi^{\circ}{ }_{a}=-1.31 \mathrm{~V}$ ambiguously depends on $\mathrm{Cl}--\mathrm{ions}$ concentration in the range from 0,1 to $1,5 \mathrm{~N} \mathrm{NaCl}$ solutions. In the first seconds, repassivation of the surface occurs by the linear law, later - by the exponential dependence, and finishes completely to 1 hour. The main stages of corrosion fatigue of titanium alloys of different structural and phase state have been indentified, on the basis of the correlation changes of the surface and the electrode potential. It has been shown that FS of the alloys demonstrates all the properties of the material that can pass into the passive state. Activation of the alloy surface is accompanied by significant discharge of the electrode potential $(-1,2 \mathrm{~V})$ and a sharp increase of current $\left(159 \mathrm{~A} / \mathrm{m}^{2}\right)$. The repassivation is characterized by a three-stage change of both the potential and the current: existence of the period after surface activation, when the potential changes slightly and lasts from 0.01 to $0.02 \mathrm{~s}$; decrease by the linear law in the first seconds; retardation and stabilization. The first period is most clearly observed on the curve "time vs passivation current". Time of almost constant current (up to 0.01 to $0.02 \mathrm{~s}$ ) does not change under cyclic deformation effect. The test results, presented in semi logarithmic coordinates (dependences $E-t$ and $i-t$ ) show that the current changes more significantly with time than the potential as well as differentiation of curves under deformation effect is more clear in the investigated environment. The character of $i$ - $t$ curves changes in deformation and without deformation is similar. However, under the effect of the last one, a more rapid decrease of current and its stabilization take place. The deformed alloy passes into a passive state more quickly than the undeformed one. The variation of the curve "current-time" with deformation and without deformation is the same, whereas, under the deformations influence the current decreases more rapidly. The kinetics and the mechanisms of corrosion-fatigue fracture of titanium alloys are analyzed. 
Key words: titanium alloys, corrosion process, electrode potential, polarization, repassivation, deformation, mechanism, electrochemical kinetics.

Постановка проблеми. У процесі вивчення електрохімічного чинника корозійної втоми виокремлюють кінетичні аспекти, які характеризують: зміна з часом електродного потенціалу, струм поляризації, імпенданс системи «метал середовище» $[1 ; 2 ; 6 ; 8 ; 9 ; 14]$, а також термодинамічні аспекти, основані на інтерпретації діаграм Пурбе (потенціал - pH) [4; 9; 13]. Термодинамічні аспекти охоплюють дані про електрохімічну та корозійну поведінку металів у водних середовищах, унаочнюють умови (область потенціалів і pH), за яких метал термодинамічно тривкий або реагує з утворенням іонів, оксидів або комплексних сполук. Однак на діаграмах відсутня інформація про швидкість реакцій, про захисні властивості дифузійно-бар'єрних плівок на поверхні електрода за наявності специфічних іонів $\left(\mathrm{Cl}^{-}, \mathrm{SO}_{4}{ }^{2-}\right)$, а також про утворення плівок нестехіометричного складу, які здебільшого суттєво впливають на швидкість корозії. 3 позиції електрохімічного механізму корозії термодинамічну можливість процесу можна оцінити електрорушійною силою корозійних елементів, сукупна дія яких і зумовлює корозійний процес. Головну експериментальну інформацію одержують за допомогою високочутливих електрохімічних методів дослідження, які дають змогу вивчати кінетику корозійного процесу [4; 6; 9, 14].

Аналіз останніх досліджень і публікацій. Традиційні методи вивчення корозійно-механічного руйнування металів грунтуються на визначенні кількості циклів навантажень або часу до руйнування зразків, що циклічно деформуються в корозійному середовищі, коли задані амплітуда змінних напруг або деформації $[2 ; 3 ; 11$; 14]. Такий підхід хоча й дає цінну інформацію щодо довговічності виробів, проте не дає змоги глибше проаналізувати стадійність руйнування. Тому останніми роками інтенсивно ведуть пошук нових кінетичних підходів до оцінки корозійномеханічного руйнування конструкційних матеріалів $[1 ; 4 ; 5 ; 11]$, які базуються на законах механіки руйнування, електрохімії, фізики твердого тіла, фізики металів та інших фундаментальних наук. Відомо [1; 5; 11], що корозійно-механічне руйнування можна розбити на ряд періодів, тривалість яких залежить від природи металу, структурно-напруженого стану досліджуваного об'єкта, умов його навантаження. Фізично розділити ці періоди досить важко, проте такий умовний розподіл доцільно зберегти для полегшення вивчення кінетики корозійно-механічного руйнування. Для вивчення періодів руйнування, зокрема першого, використовують металографію, рентгенографічний, магнетометричний, резистометричний, акустичний, електрохімічний та інші аналізи, що фіксують зміну тонкої структури i фізико-хімічного стану поверхневих шарів металу $[1 ; 2 ; 5 ; 14]$.

Постановка завдання. Наше завдання підсумувати кінетичні закономірності електрохімічного процесу корозійної втоми титанових сплавів для 3'ясування особливостей їхнього корозійновтомного руйнування, вибір на цій основі сплавів для конкретних умов експлуатації та методів підвищення їхньої корозійно-циклічної довговічності.

Матеріали та методика досліджень. Механізм і кінетику корозійновтомного руйнування титанових сплавів ми досліджували за зміною електродного потенціалу $E$ під час деформації зразків (залежності $E-\lg N[4 ; 5])$. Використано дані про перебіг електрохімічних процесів на недеформованій та деформованій [6] неперервно оновлюваних поверхнях, демонструючи зміну кінетики формування оксидних плівок на свіжоутворених поверхнях (СУП) титанових сплавів без і за наявності циклічного деформування.

Випробовували на втому циліндричні зразки діаметром $5 \mathrm{~mm}$ із технічно чистого титану марки ВТ1-0 та сплавів різної структури: $\alpha$ - ВТ-5; псевдо- $\alpha$ - ПТ-3В та $(\alpha+\beta)-$ ПТ-5В, ВТ-14 навантаженням чистим згином 3 обертанням за частоти $50 \mathrm{~s}^{-1}$ у розчині хлориду натрію різної концентрації. Електродом порівняння був насичений хлоросрібний електрод. Використовували потенціостат П-5848.

Електрохімічні властивості СУП вивчали методами, за якими можна визначати час утворення поверхні [1]. Утворення захисних оксидних плівок на недеформованих і циклічно деформованих титанових $\alpha-\mathrm{i}(\alpha+\beta)$-сплавах констатували, усуваючи з їхньої поверхні оксиди і визначаючи зміщення потенціалу та поведінку за зовнішньої поляризації, а також після призупинення оновлення поверхні - за швидкістю зміни електродного потенціалу та струму $[7 ; 8]$.

Здатність до регенерації пасивності сплавів за умов циклічного деформування оцінювали під час поляризації поверхні потенціалом $E_{p o l}$, що відпо- 
відав потенціалу корозії $E_{\text {corr }}=460 \mathrm{mV}$, активацію та репасивацію поверхні - за зміною потенціалу та струму 3 часом: криві $E-t$ та $i-t$. Потенціали СУП отримано для частоти обертання електрода $50 \mathrm{~s}^{-1}$, що відповідало лінійній швидкості руху $0,785 \mathrm{~m} / \mathrm{s}$ (за вибраної конструкції елементів зачистки), час взаємодії СУП із розчином $5 \mathrm{~ms}$. Зусилля притискання елементів зачистки (40 N) гарантувало однакову чистоту поверхні. Зміну зміщення потенціалу записували осцилографом типу $\mathrm{C} 1-17$, а осцилографічні траси фотографували.

Вимірювали $E$ блоком високоомного вольтметра потенціостата із записом у часі реєстрованого сигналу за допомогою самописця. Точність вимірювання потенціалу $\pm 0,2 \mathrm{mV}$.

Виклад основного матеріалу. Електрохімія гладких зразків. Чутливість електродного потенціалу до зміни стану поверхні металу дуже висока i дає змогу навіть зафіксувати початок пластичної деформації в мікрооб' ємах, що неможливо зробити стандартними механічними випробуваннями $[1 ; 6 ;]$. Під циклічними напруженнями кінетика потенціалу має складніший вигляд, аніж під дією постійних напружень, і залежить від типу системи «матеріал - середовище». Зважаючи на певну ідентичність отримуваних у процесі корозійновтомного випробування кінетичних закономірностей електродного потенціалу [11; 12], їх можна виразити типовою кривою 3 характерними ділянками, що відповідають окремим етапам корозійновтомного руйнування титанових сплавів (рис. $1, a$ ): руйнування поверхневих оксидних плівок унаслідок деформації та поява ювенільних поверхонь металу (різкий зсув потенціалу в момент навантаження - перший етаn); пасивація сформованих під навантаженням ювенільних поверхонь (зміщення потенціалу в більш додатну область значень - другий етаn); збільшення гетерогенності поверхні, зародження мікротріщин, ïх зростання до макроскопічних розмірів (стабілізація потенціалу циклічно деформованого зразка у від'ємнішій області порівняно з ненавантаженим - третій етаn); ріст магістральної тріщини, руйнування зразка (різке зміщення потенціалу в катодну область - четвертий етаn). Стрибок потенціалу на останньому етапі зумовлений інтенсивним утворенням свіжої поверхні в тріщині, що розвивається. Фіксована величина потенціалу в момент руйнування не залежить від початкового рівня прикладених амплітудних напруг.

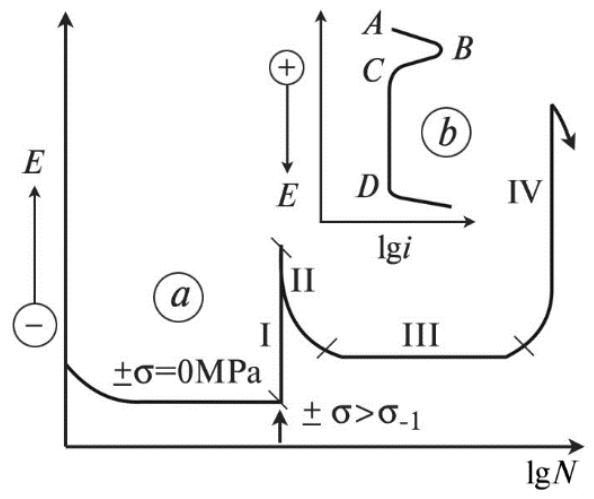

Рис. 1. Типова зміна електродного потенціалу під час циклічного деформування $(a)$ і схематична залежність швидкості розчинення від потенціалу $(b)$ Fig. 1. Typical change of the electrode potential during cyclic deformation $(a)$ and dependence of the dissolution rate on the potential $(b)$

Електродний потенціал недеформованого зразка, що обертається $( \pm \sigma=0 \mathrm{MPa})$, інтенсивно ошляхетнюється протягом 10-15 $\mathrm{min}$, Згодом швидкість зміщення в позитивну область значень дещо зменшується, остаточно стабілізуючись через 25-30 $\mathrm{min}$. На першій ділянці, тобто в момент циклічного навантаження, зміна потенціалу титану та сплавів [5] становить $140 \ldots 320 \mathrm{mV}$ відносно значення для недеформованого зразка, що обертається.

Зазначимо, що для титанових сплавів, на відміну від вуглецевих і нержавіючих сталей [2; $11 ; 14]$, характерна наявність ділянки інтенсивного відновлення пасивного стану після їх навантаження (другий етап). Це, а також відсутність зв'язку між величиною зміщення потенціалу та рівнем прикладених напружень (перший етап), свідчить про те, що зміна потенціалу на цьому етапі спричинена головно руйнуванням пасивної плівки. Стабілізація потенціалу на другому етапі відбувається за більш негативних значень порівняно зі стабілізованим значенням потенціалу ненавантаженого зразка. Це пояснюється, крім термодинамічної та деформаційної активації поверхні металу, утворенням на такій поверхні менш досконалих захисних плівок. На зміну електродного потенціалу за корозійної втоми впливають основні легуючі елементи титанових сплавів (алюміній, ванадій, молібден, хром), що корелює $з$ результатами впливу корозійного середовища на циклічну довговічність сплавів [5; 6].

Типова крива кінетики електродного потенціалу при корозійній втомі (залежності $E-\lg N$, див. рис. $1, a$ ) подібна до «класичної» кривої $E$ $\lg i$ швидкості розчинення металу від потенціалу 3 
максимумом струму в точці $E=E_{\text {pas }}$ (див. рис. 1, $b)$. Ділянка $A B$ кривої на рис. $1, b$ відповідає області потенціалів $E$, за якої метал перебуває в активному стані та характеризується зростанням логарифма струму розчинення металу під час зміщення $E$ в додатному напрямку. Перегин кривої в точці $B$ вказує на різке зниження струму під час подальшого зміщення $E$ в додатному напрямку. 3 досягненням цього потенціалу метал переходить 3 активного в пасивний: швидкість його розчинення різко зменшується та не змінюється 3 подальшим збільшенням $E$ до деякої границі (точка $D$ на рис. $1, b$ ). Зсув $E$ від цієї точки в додатному напрямку зумовлює нове активування металу.

Регенерація захисної плівки. Руйнування захисного оксидного шару - одна 3 необхідних, але недостатніх умов прояву корозійної втоми титанових сплавів [2]. Щоб вивчити кінетику регенерації захисної оксидної плівки на титанових сплавах у хлоридних розчинах, досліджували електрохімічні властивості СУП.

СУП різних твердих металів для отримання чистих, хоча й деформованих, поверхонь 3 метою вивчення початкових стадій електродних реакцій на таких поверхнях використовують досить давно [2; 14]. Описано велику кількість методів отримання СУП залежно від конкретної мети. Ми вивчали кінетику утворення захисних оксидних плівок у хлоридних середовищах методами, в основу яких покладено зміну величини зміщення потенціалу електрода досліджуваного сплаву в разі усунення 3 його поверхні оксидів, а також швидкість зміни електродного потенціалу та струму поляризації після оновлення поверхні [5; 7].

За відсутності прикладених напружень титанові сплави покриті хімічно неактивною плівкою, склад і структура якої змінюються в широких межах від $\mathrm{TiO}$, за умови м'якого окиснення, до $\mathrm{TiO}_{2}$ зі структурою рутилу й анатазу, в умовах енергійнішого окиснення [7]. Нестехіометричні оксиди типу $\mathrm{TiO}_{2-x}$ проявляють напівпровідникові властивості. Оксид $\mathrm{TiO}_{2}$ зі структурою рутилу та анатазу наближається до діелектриків. Товщини оксидних шарів на титані, залежно від умов, коливаються в широких межах: від 1,0-1,2 nm до десятків нанометрів і більше [7].

Пасивна плівка, втрачаючи суцільність під час механічного руйнування або появи смуг ковзання, відразу не регенерується, оскільки потрібний певний час для того, щоб метал вступив у взаємодію 3 молекулами води або аніонами розчину. Тут доречні результати досліджень Бека
[6] 3 пасивації ювенільних поверхонь титану, отриманих розривом титанового дроту (стрижнів) у $3 \mathrm{~N}$ розчині $\mathrm{HCl}$ та $\mathrm{H}_{2} \mathrm{SO}_{4}$. Плівка (моношар оксиду) утворювалася за дуже короткий проміжок часу $(0,1 \ldots 10 \mathrm{~ms})$. Упродовж цього часу іони металу переходять у розчин до призупинення реакції. Унаслідок розчинення металу потік електронів проходить через метал до катода, тож, якщо скористатися електродом порівняння, можна визначити величину потенціалу.

Виявлено значні від’ємні значення потенціалу СУП сплавів у водних розчинах хлориду натрію різної концентрації (рис. 2). За час оновлення поверхні та іiі контакту зі середовищем $(\tau=5 \mathrm{~ms})$ електрохімічні реакції різко гальмуються, у цьому разі суттєво утруднюється катодний процес. Це i знешляхетнює потенціал СУП та зміщує його до зворотного потенціалу анодної реакції $\varphi_{a}^{0}$.

$\varphi^{0}{ }_{a}$ для титану у водних розчинах хлориду натрію для реакції $\mathrm{Ti}+\mathrm{H}_{2} \mathrm{O}=\mathrm{TiO}+2 \mathrm{H}^{+}+2 \overline{\mathrm{e}}$ становить $-1,31$ V (н. в. е.) [12]. Порівняння потенціалів СУП сплавів з наведеним для титану $\varphi^{0}{ }_{a}$ свідчить, що на оновленій поверхні сплавів можливий інтенсивний анодний процес завдяки реакції іонізації атомів металу. Потенціали СУП неоднозначно залежать від концентрації $\mathrm{Cl}^{-}$-іонів під час зачищення поверхні різнорідними елементами. Зі збільшенням концентрації іонів у процесі оновлення поверхні сплавів абразивом К340 потенціал СУП неперервно знешляхетнюється (від $-1,24$ до $-1,27 \mathrm{~V}$ ), тоді як під час зачистки елементами зі сплаву ВТ14 та сталі 45 максимально потенціал $E_{s o p}$ зміщується в $0,5 \mathrm{~N}$ розчині $\mathrm{NaCl}$. Потенціал СУП сплавів залежить також від матеріалу елемента оновлення поверхні та знешляхетнюється в такому ряду: сталь $45 \rightarrow$ сплав ВТ14 $\rightarrow$ абразив К340. У досліджених розчинах за вибраних елементів оновлення $E_{\text {sop }}$ від'ємніший для сплаву ВТ5 унаслідок легування його алюмінієм. Така залежність потенціалу СУП сплавів від зміни концентрації $\mathrm{Cl}^{-}$-іонів підтверджує, що розчинення за цих умов лімітується сполуками, властивості яких залежать від концентрації розчину, його аніонного складу. Суттєве ушляхетнення потенціалу СУП сплавів під час зачистки сталлю 45 пояснюється ще й активізацією катодного процесу з уведенням у розчини іонів $\mathrm{Fe}^{2+}, \mathrm{Fe}^{3+}$, які є деполяризаторами катодної реакції [12].

Регенерація захисної оксидної плівки на сплавах в $0,1 \ldots 1,5 \mathrm{~N}$ розчинах $\mathrm{NaCl}$ (рис. 3) супроводжується спадом потенціалу в перші секунди за лінійним законом із подальшим 
уповільненням і стабілізацією протягом $1 \mathrm{~h}$. Початкова стадія утворення плівки до товщини декількох моношарів найімовірніше проходить шляхом формування «плям», які зароджуються, можливо, у декількох сприятливих місцях i розростаються в ширину. Наступний ріст плівки може контролюватися дифузією, яка змінює характер затухання.

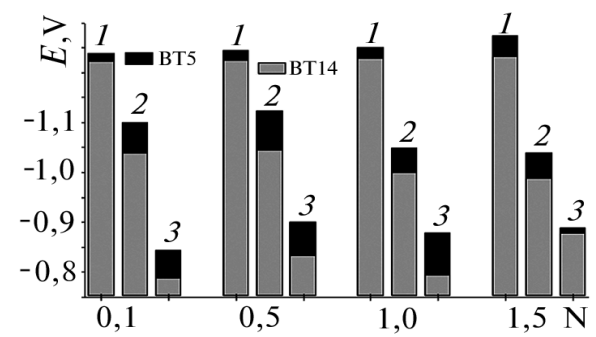

Рис. 2. Зміна величини зміщення потенціалу СУП ( $\tau=5 \mathrm{~ms})$ у розчинах $\mathrm{NaCl}$ різної концентрації залежно від природи елементів зачистки: 1 - абразив КЗ340;

2 - сплав ВТ 14; 3 - сталь 45

Fig. 2. Change of the fresh surface (FS) potential ( $\tau \sim 5$ $\mathrm{ms}$ ) shift depending on the character of friction elements in $\mathrm{NaCl}$ solution of different concentration: 1 - K340 abrasive; 2 - BT14 alloy; 3 - 45 steel
Початкову лінійну зміну потенціалу використано для визначення швидкості репасивації $\left(V_{r}\right): V_{r}=\Delta E / \Delta \tau=\operatorname{tg} \alpha$, де $\alpha-$ кут нахилу лінійної частини кривих. Швидкість зміни потенціалу для кривих, зображених на рис. $3, a\left(V_{r}\right.$ в 0,$1 ; 0,5 ; 1,0$ та $1,5 \mathrm{~N}$ розчинах $\mathrm{NaCl}$ відповідно $220,239,252$ та $263 \mathrm{mV} / \mathrm{s})$, свідчить про інтенсивну репасивацію СУП сплавів. Зауважимо, що чим більше знешляхетнення потенціалу під час оновлення поверхні, тим інтенсивніша іiі репасивація.

Експериментальні залежності зміни електродного потенціалу після призупинення оновлення поверхні сплавів у хлоридних розчинах різної концентрації добре апроксимуються аналітичним виразом [7]:

$$
E=E_{\text {sop }} \cdot E_{n}\left[t_{n} /\left(t \sqrt[m]{E_{\text {sop }}}-\sqrt[m]{E_{n}}\left(t-t_{n}\right)\right)^{-1}\right]^{m},
$$

де $E$ - потенціал у момент часу $t$, який визначається 3 граничних умов, що при $t=0$ потенціал СУП дорівнюе $E_{\text {sop, }}$ а в деякий проміжковий час $t_{n}\left(t_{n}=20 \ldots 30 \mathrm{~s}\right.$ залежно від сплаву) величина $E_{n}$ відносно стабілізується. Визначивши $E_{\text {sop }}$ i $E_{n}$ у перші секунди, можна достатньо точно (відносна похибка $<3 \%$ ) обчислити значення потенціалу в проміжку $1,5 \ldots 2,0 \mathrm{~h}$.
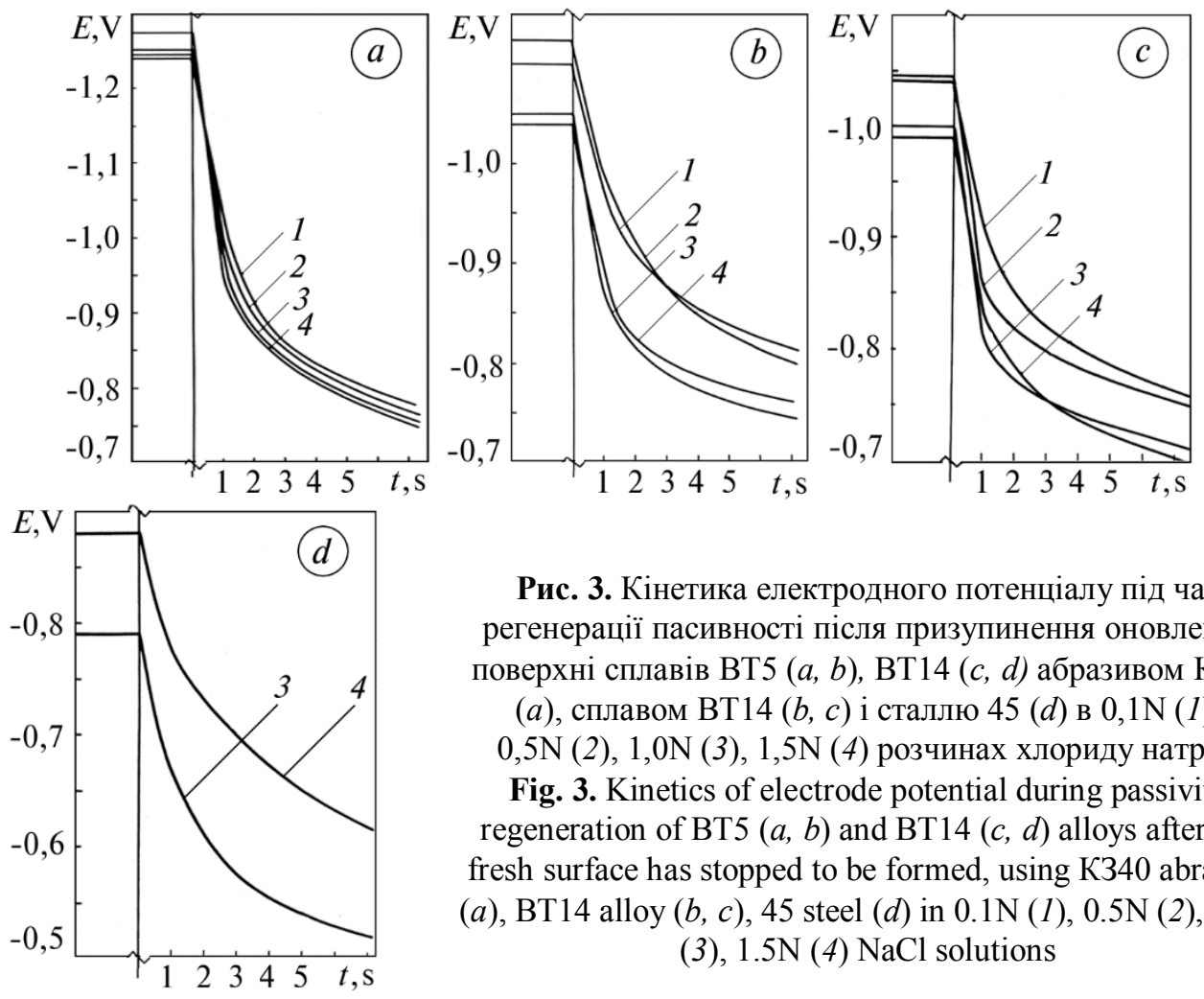

Рис. 3. Кінетика електродного потенціалу під час регенерації пасивності після призупинення оновлення поверхні сплавів $\mathrm{BT} 5(a, b)$, ВТ14 $(c, d)$ абразивом К340

$(a)$, сплавом ВТ14 $(b, c)$ і сталлю $45(d)$ в $0,1 \mathrm{~N}(1)$,

$0,5 \mathrm{~N}(2), 1,0 \mathrm{~N}(3), 1,5 \mathrm{~N}(4)$ розчинах хлориду натрію

Fig. 3. Kinetics of electrode potential during passivity regeneration of BT5 $(a, b)$ and BT14 $(c, d)$ alloys after the fresh surface has stopped to be formed, using K340 abrasive $(a)$, BT14 alloy $(b, c), 45$ steel $(d)$ in $0.1 \mathrm{~N}(1), 0.5 \mathrm{~N}(2), 1.0 \mathrm{~N}$ (3), $1.5 \mathrm{~N}(4) \mathrm{NaCl}$ solutions 

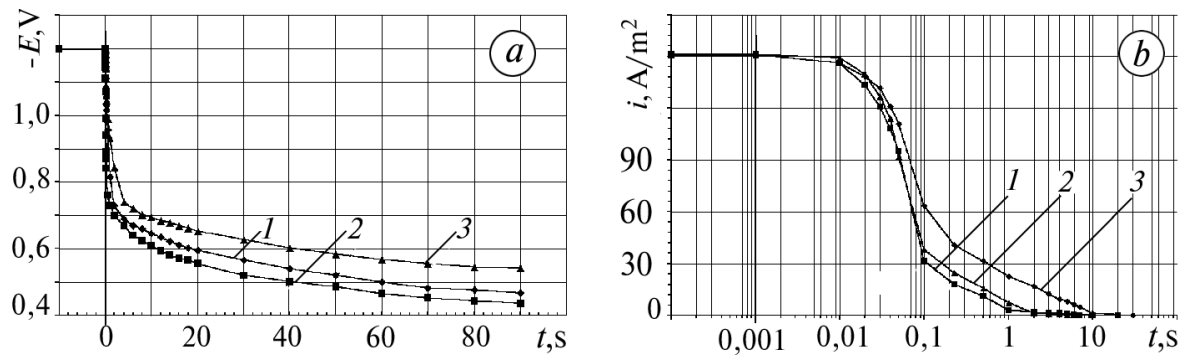

Рис. 4. Часова залежність потенціалу $(a)$ і струму $(b)$ репасивації сплаву ПТ-5В у 3 \%-му розчині $\mathrm{NaCl}$ від деформації: 1 - недеформований; 2 - під напруженням $450 \mathrm{MPa}$; 3 - під напруженням $470 \mathrm{MPa}$

Fig. 4. Time dependence of the repassivation potential $(a)$ and current $(b)$ of $\Pi \mathrm{T}-5 \mathrm{~B}$ alloy in $3 \% \mathrm{NaCl}$ solution, depending on deformation: 1 - non-deformed; 2 - under stress of $450 \mathrm{MPa} ; 3$ - under stress of $470 \mathrm{MPa}$

$3 E-t$ кривих (див. рис. 3) випливає також, що зміна хімічного складу та структури сплавів, концентрації розчину, матеріалу елементів оновлення суттєво впливає, як і за неперервного оновлення, на швидкість регенерації пасивності на характерних іiі ділянках. Вплив хімічного складу сплавів та їхньої структури пов'язаний із тим, що в структурі наявні мікрооб'єми (фази або сегрегації легуючих елементів) із більш від’ємним потенціалом, аніж матриця. Поки захисна плівка не зруйнована, електрохімічні властивості цих об'ємів стабільні. Після руйнування пасивного захисного шару ці мікрооб'єми, які мають відмінний від матриці ізобарний електрохімічний потенціал, сприяють зниженню компромісного потенціалу та зростанню анодного струму, що й зумовлює зниження швидкості регенерації пасивності. Однак загалом переважає гальмування анодного процесу, тому потенціал активно ошляхетнюється. Різний вплив концентрації розчину хлориду натрію, ймовірно, зумовлений неідентичною роллю $\mathrm{Cl}^{-}$-іонів в утворенні репасиваційних плівок після оновлення поверхні різнорідними матеріалами. Зміна потенціалу, аж до стабілізації, зумовлена поліпшенням захисних властивостей репасиваційної плівки та не супроводжується значними змінами швидкості електродних реакцій.

Вилив деформації чистим згином з обертанням на здатність титанового $(\alpha+\beta)$-сплаву ПТ-5В системи Ti-Al-V-Mo до регенерації пасивності оцінено в $3 \%$-му розчині хлориду натрію (рис. 4).

Порушення пасивного стану сплаву без і за наявності циклічного деформування (зачистка) [10] супроводжується значним знешляхетненням потенціалу активації $(-1,2 \mathrm{~V})$ (див. рис. $4, a)$ та різким зростанням струму $\left(159 \mathrm{~A} / \mathrm{m}^{2}\right)$ (див. рис. $\left.4, b\right)$. Величини i потенціалу, і струму свідчать про інтенсивний перебіг на СУП анодного процесу внаслідок реакції іонізації атомів металу. Регенерації пасивності сплаву, після призупинення оновлення поверхні, притаманні спад потенціалу за лінійним законом у перші секунди, гальмування та його стабілізація (див. рис. $4, a$ ). Дещо інший характер зміни виявляється 3 напівлогарифмічної залежності струму регенерації захисної плівки (див. рис. $4, b)$. На перших двох ділянках репасивація описується прямою лінією за різних значень кутового коефіцієнта. На третій струм дорівнює значенню оновлення поверхні. Простежується також значніша його зміна 3 часом, аніж потенціалу, та чіткіша диференціація кривих залежно від деформації. Характер зміни $I-t$ кривих без та за наявності деформації однаковий, але під дією деформації струм знижується інтенсивніше і за час експозиції до $10 \mathrm{~s}$ досягає стаціонарного значення.

Аналіз численних досліджень кінетики розчинення титану в хлоридних розчинах дає підстави вважати підсумковим (результуючим) такий механізм [7; 8]:

$\mathrm{Ti}+\mathrm{H}_{2} \mathrm{O}+2 \mathrm{Cl}^{-} \rightarrow \mathrm{TiOCl}_{2}+2 \mathrm{H}^{+}+4 \overline{\mathrm{e}}$.

Поверхневий оксіхлорид титану піддається повному гідролізу:

$\mathrm{TiOCl}_{2}+3 \mathrm{H}_{2} \mathrm{O} \rightarrow \mathrm{Ti}(\mathrm{OH})_{4}+2 \mathrm{HCl}$

3 подальшою можливою дегідратацією гідроксиду титану й утворенням діоксиду титану:

$$
\mathrm{Ti}(\mathrm{OH})_{4} \rightarrow \mathrm{TiO}_{2}+2 \mathrm{H}_{2} \mathrm{O} \text {. }
$$

Можна стверджувати, що в розчиненні титанових сплавів під час регенерації пасивності у водних розчинах нейтральних солей за потенціалу $E_{p o l} \approx E_{c o r r}$ безпосередньо задіяні аніони солей та простежується попередня адсорбція цих аніонів на електроді з утворенням поверхневих сполук унаслідок адсорбційної взаємодії 3 металевою поверхнею.

\section{Висновки}

1. На підставі кореляційних змін на поверхні й електродного потенціалу з'ясовано характерні 
ділянки, які відповідають окремим етапам процесу корозійної багатоциклової втоми сплавів. Ідентифіковано основні стадії процесу корозійної втоми титанових сплавів різного структурно-фазового стану: руйнування захисних оксидних плівок; пасивація СУП; утворення мікротріщин та їх розвиток у макротріщину; субкритичний ріст магістральної тріщини та спонтанне руйнування.

2. Потенціал СУП титанових сплавів ( $\tau=5 \mathrm{~ms}$ ) знешляхетнюється та наближається до величини зворотного потенціалу анодної реакції $\mathrm{Ti}+\mathrm{H}_{2} \mathrm{O}=\mathrm{TiO}+2 \mathrm{H}^{+}+2 \bar{e}\left(\varphi^{0}{ }_{a}=-1,31 \mathrm{~V}\right)$, неоднозначно залежить від концентрації $\mathrm{Cl}^{-}$-іонів у діапазоні 0,1-1,5 N розчинів $\mathrm{NaCl}$. Регенерація пасивності сплавів у перші секунди відбувається за лінійним законом із подальшим уповільненням і стабілізацією до 1 h. Концентрація розчину, хімічний склад сплаву та природа елементів оновлення суттєво впливають на процес репасивації, що $\epsilon$ свідченням трансформації первинних захисних плівок за 1-4 s інтенсивної зміни потенціалу.

3. Порушення пасивного стану титанових сплавів за наявності циклічного деформування (активація) супроводжується значним знешляхетненням потенціалу активації $(-1,2 \mathrm{~V})$ та різким зростанням струму $\left(159 \mathrm{~A} / \mathrm{m}^{2}\right)$. Регенерація пасивності циклічно деформованих сплавів характеризується етапною зміною і потенціалу, і струму. На перших етапах їхній спад описується прямою лінією в координатах напруга (струм) - логарифм часу експозииії за різних кутових коефіцієнтів. На третьому етапі потенціал СУП досягає значення, що дорівнює потенціалу сплаву до оновлення поверхні. Характер зміни $i-t$ кривих без і за наявності деформацій однаковий, але під дією деформації струм знижується швидше і за час експозиції до $10 \mathrm{~s}$ зменшується до стаціонарного значення.

\section{Бібліографічний список}

1. А. с. 954859 (СССР). Способ испытания материалов на усталость / В. И. Похмурский, О. С. Калахан, Н. Я. Яремченко. Опубл. 30.08.82, Бюл. № 26.
2. Дмитрах I. М., Панасюк В. В. Вплив корозійних середовищ на локальне руйнування металів біля концентраторів напружень. Львів: НАН України, Фіз.-мех. ін-т ім. Г. В. Карпенка, 1999. 341 с.

3. Дмитрах I. М., Сиротюк А. М., Лещак Р. Л. Руйнування та міцність трубних сталей у водневмісних середовищах. Львів: Простір-М, 2020. 222 с.

4. Калахан О. Електрохімія корозійно-втомних процесів титанових сплавів. Вісник Львівського університету. Сер. хім. 2002. Вип. 42. С. 175-178.

5. Калахан О. С. Вплив деформації титанових сплавів на кінетику утворення захисних оксидних плівок. Фіз.-хім. механіка матеріалів. 2002. № 3, т. 1. C. $172-176$.

6. Романив О. Н. Новые подходы к оценке коррозионной усталости металлов. Коррозия и защзита от коррозии (Итоги науки и техники). Москва: ВИНИТИ, 1990. $88 \mathrm{c.}$

7. Рускол Ю. С. Титановые конструкционные сплавы в химических производствах: справ. изд. Москва: Химия, 1989. 288 с.

8. Створення сучасних методів технічної діагностики працездатності систем пароводяного тракту енергоблоків TEC / I. М. Дмитрах, А. М. Сиротюк, Б. П. Русин, Ю. В. Лисак, А. Б. Вайнман. Проблеми ресурсу $i$ безпеки експлуатаиії конструкиій, споруд $i$ машин: зб. наук. статей / наук. керівник Б. С. Патон. Київ: Ін-т електрозварювання ім. Є. О. Патона НАН України, 2006. С. 128-132.

9. Технічна діагностика матеріалів i конструкцій: довід. посіб.: у 8 т. / за заг. ред. 3. Т. Назарчука. Т. 6: Електрохімічні методи моніторингу деградації матеріалу конструкцій. Львів: Простір-М, 2017. 302 c.

10. Encyclopedia of electrochemistry / ed. by A. G. Bard and M. Stratmann. Vol. 4: Corrosion and Oxide Fils. Weinheim (Germany): Wieley-VCH, 2003. 542 p.

11. Kalakhan O. S. Kinetic regularities of the electrochemical processes of corrosion fatigue in titanium alloys. Materials Science. 2003. 39 (5). C. 615-628.

12. Kalakhan O. S. Kinetic regularities of electrochemical processes of titanium alloys corrosion fatigue. Fiziko-khimicheskaya mekhanika materialov. 2003. 39 (5). P. 14-27.

13. Pourbaix M. Atlas of Electrochemical Equilibria in Aqueous Solution. New York: Pergamon Press, 1966. $1243 \mathrm{p}$.

14. Pokhmurskii V. I., Kalakhan O. S., Okhota H. H. Corrosion Electrochemical Behavior of Surface-Modified Titanium Alloys. Materials Science. 2005. Vol. 41, No. 1. P. 1-6. 